\title{
Controlled Self-Assembly of Gold Nanoparticles Mediated by Novel
}

\section{Organic Molecular Cages}

Wounjhang Park ${ }^{1, *}$, Kazunori Emoto ${ }^{1}$, Yinghua Jin, ${ }^{2}$ Akihiro Shimizu, ${ }^{1}$ Venkata

A. Tamma, ${ }^{1}$ and Wei Zhang ${ }^{2, *}$

${ }^{1}$ Department of Electrical, Computer \& Energy Engineering,

${ }^{2}$ Department of Chemistry and Biochemistry, University of Colorado, Boulder, CO 80309, U.S.A.

\section{Supporting Information:}

\section{Materials and general synthetic methods}

Reagents and solvents were purchased from commercial suppliers and used without further purification, unless otherwise indicated. Ether, tetrahydrofuran, toluene, $\mathrm{CH}_{2} \mathrm{Cl}_{2}$ and $\mathrm{DMF}$ are purified by solvent purification systems.

All reactions, except those performed in aqueous solvent, were conducted under dry nitrogen in oven-dried glassware. Unless otherwise specified, solvents were evaporated using a rotary evaporator after workup.

Flash column chromatography was performed by using a 100-150 times weight excess of flash silica gel 32-63 $\mu \mathrm{m}$. Fractions were analyzed by TLC using TLC silica gel precoated-plates.

NMR spectra were taken on Inova 400 and Inova 500 spectrometers. $\mathrm{CHCl}_{3}(7.26 \mathrm{ppm})$ was used as internal references in ${ }^{1} \mathrm{H} \mathrm{NMR}$, and $\mathrm{CHCl}_{3}$ (77.23 ppm) for ${ }^{13} \mathrm{C}$ NMR. ${ }^{1} \mathrm{H}$ NMR data were reported in order: chemical shift, multiplicity (s, singlet; $d$, doublet; $t$, triplet; q, quartet; m, multiplet), number of protons, coupling constants $(J, \mathrm{~Hz})$, and assignments. 


\section{Cage Molecule Synthesis}

Synthesis of COP-1: To a solution of 1,3,5-trihexyl-2,4,6-tris(4aminophenyl)benzene (428 $\mathrm{mg}, \quad 0.71 \mathrm{mmol})$ and 10-bromo-1,8diformylanthracene (335 mg, $1.07 \mathrm{mmol})$ in chloroform $(237 \mathrm{~mL})$ was added a solution of TFA $(8 \mu \mathrm{L}, 0.11 \mathrm{mmol})$ in $\mathrm{CHCl}_{3}(100 \mu \mathrm{L})$ slowly dropwise. The solution was stirred at $\mathrm{rt}$ for $18 \mathrm{~h}$, at which time ${ }^{1} \mathrm{H}$ NMR spectrum of the concentrated crude reaction mixture indicated both of the starting materials were consumed. The solution was cooled to $-45^{\circ} \mathrm{C}$, and DIBAL-H (21.3 mL, $21.3 \mathrm{mmol}, 1.0 \mathrm{M}$ in $\left.\mathrm{CH}_{2} \mathrm{Cl}_{2}\right)$ was added. After stirring at $-45{ }^{\circ} \mathrm{C}$ for $30 \mathrm{~min}$, the reaction was quenched with $\mathrm{MeOH}(1 \mathrm{~mL})$, and satd. $\mathrm{NaHCO}_{3}(100 \mathrm{~mL})$ was added. The mixture was stirred at $\mathrm{rt}$ for 30 min, and the organic layer was separated. The aqueous solution was extracted with $\mathrm{CHCl}_{3}(3 \times 75 \mathrm{~mL})$. The combined organics were dried over $\mathrm{Na}_{2} \mathrm{SO}_{4}$, and concentrated. The residue was dissolved in THF $(5 \mathrm{~mL})$, and slowly added to $\mathrm{MeOH}(150 \mathrm{~mL})$ dropwise. The pure product precipitated as a yellow solid, and was collected by filtration (478 mg, $66 \%)$ : ${ }^{1} \mathrm{H}$ NMR $\left(500 \mathrm{MHz}, \mathrm{CDCl}_{3}\right) \delta 9.12(\mathrm{~s}, 3 \mathrm{H}), 8.63-8.44(\mathrm{~m}, 6 \mathrm{H}), 7.64-7.52(\mathrm{~m}, 12 \mathrm{H})$, $7.17(\mathrm{~d}, J=13.6 \mathrm{~Hz}, 6 \mathrm{H}), 6.95-6.79(\mathrm{~m}, 12 \mathrm{H}), 6.65(\mathrm{dd}, J=8.1,2.1 \mathrm{~Hz}, 6 \mathrm{H})$, $4.82(\mathrm{~s}, 12 \mathrm{H}), 3.67(\mathrm{~s}, 6 \mathrm{H}), 2.38-2.06(\mathrm{~m}, 12 \mathrm{H}), 1.29-1.20(\mathrm{~m}, 12 \mathrm{H}), 1.07-$ $0.97(\mathrm{~m}, 12 \mathrm{H}), 0.95-0.79(\mathrm{~m}, 24 \mathrm{H}), 0.68(\mathrm{t}, J=7.3 \mathrm{~Hz}, 18 \mathrm{H}) ;{ }^{13} \mathrm{C}$ NMR $(101$ $\left.\mathrm{MHz}, \mathrm{CDCl}_{3}\right) \delta 146.5,139.7,139.4,136.0,133.0,132.1,131.1,130.9,130.4$, 128.5, 127.1, 124.2, 120.2, 114.5, 111.4, 47.4, 32.2, 31.4, 31.3, 29.9, 22.6, 14.4; MS (MALDI) calc'd for $\mathrm{C}_{132} \mathrm{H}_{141} \mathrm{Br}_{3} \mathrm{~N}_{6}([\mathrm{M}+])$ 2051.88, found 2050.61.

Synthesis of COP-3P: In a Schlenk tube, COP-1 $(85 \mathrm{mg}, 0.04$ mmol), pyridine-4-boronic acid (33 mg, $0.27 \mathrm{mmol}), \mathrm{Pd}\left(\mathrm{PPh}_{3}\right)_{4}(7 \mathrm{mg}, 0.006$ mmol), and $\mathrm{Na}_{2} \mathrm{CO}_{3}(65 \mathrm{mg}, 0.62 \mathrm{mmol})$ were added. The reaction 
apparatus was then evacuated and refilled with nitrogen. Toluene $(1 \mathrm{~mL})$, THF $(1 \mathrm{~mL})$, and $\mathrm{H}_{2} \mathrm{O}(0.5 \mathrm{~mL})$ were added.The mixture was degassed three times before heating at $105^{\circ} \mathrm{C}$ for $2 \mathrm{~d}$. Dichloromethane $(50 \mathrm{~mL})$ was added, and the mixture was washed with satd. $\mathrm{NaHCO}_{3}(30 \mathrm{~mL})$, and brine $(30 \mathrm{~mL})$. The organic solution was dried over $\mathrm{Na}_{2} \mathrm{SO}_{4}$, and concentrated to give the crude product. Purification by flash column chromatography using $10 \%$ methanol in toluene $(\mathrm{v} / \mathrm{v})$ yielded COP-3P as a light yellow solid (61 mg, $73 \%):{ }^{1} \mathrm{H}$ NMR (500 MHz, $\left.\mathrm{CDCl}_{3}\right) \delta 9.22$ (s, $3 \mathrm{H}), 8.94-8.82(\mathrm{~m}, 6 \mathrm{H}), 7.59(\mathrm{~d}, J=6.7 \mathrm{~Hz}, 6 \mathrm{H}), 7.55(\mathrm{~d}, J=8.8 \mathrm{~Hz}, 6 \mathrm{H})$, $7.45-7.34(\mathrm{~m}, 12 \mathrm{H}), 7.22(\mathrm{dd}, J=11.1,5.5 \mathrm{~Hz}, 6 \mathrm{H}), 6.97-6.86(\mathrm{~m}, 12 \mathrm{H})$, $6.69(\mathrm{dd}, J=8.1,2.4 \mathrm{~Hz}, 6 \mathrm{H}), 4.88(\mathrm{~s}, 12 \mathrm{H}), 3.84(\mathrm{~s}, 6 \mathrm{H}), 2.36-2.23(\mathrm{~m}$, $12 \mathrm{H}), 1.36-1.27(\mathrm{~m}, 12 \mathrm{H}), 1.11-1.01(\mathrm{~m}, 12 \mathrm{H}), 0.99-0.83(\mathrm{~m}, 24 \mathrm{H}), 0.69(\mathrm{t}$, $J=7.3 \mathrm{~Hz}, 18 \mathrm{H}) ;{ }^{13} \mathrm{C}$ NMR $\left(75 \mathrm{MHz}, \mathrm{CDCl}_{3}\right) \delta 150.3,148.0,146.6,139.8$, 139.5, 135.9, 135.2, 133.1, 132.1, 130.4, 129.9, 126.7, 126.0, 120.6, 114.5, 111.3, 47.4, 32.3, 31.3, 30.0, 22.7, 14.4; MS (MALDI) calc'd for $\mathrm{C}_{147} \mathrm{H}_{153} \mathrm{~N}_{9}([\mathrm{M}+])$ 2045.85, found 2045.33.

Synthesis of COP-6VP: COP-2 was prepared as previously reported (Ref. 13 in the manuscript). In a Schlenk tube, COP-2 (100 mg, $0.03 \mathrm{mmol})$, 4-vinylpyridine (38 mg, $0.36 \mathrm{mmol}) \mathrm{Pd}(\mathrm{OAc})_{2}(1 \mathrm{mg}, 0.004$ mmol) and $\mathrm{P}(\mathrm{PhMe})_{3}(1 \mathrm{mg}, 0.003 \mathrm{mmol})$ were added. The reaction apparatus was then evacuated and refilled with nitrogen three times. DMF $(1 \mathrm{~mL})$, and $\mathrm{Et}_{3} \mathrm{~N}(0.5 \mathrm{~mL})$ were added and the mixture was degassed three times before heating at $160{ }^{\circ} \mathrm{C}$ for $18 \mathrm{~h}$. The mixture was cooled to $\mathrm{rt}$, and dichloromethane $(50 \mathrm{~mL})$ was added. The mixture was washed with water $(30 \mathrm{~mL})$, and brine $(30 \mathrm{~mL})$. The organic solution was dried over $\mathrm{Na}_{2} \mathrm{SO}_{4}$, and concentrated to give the crude product. Purification by flash column chromatography (gradient elution, 2\% 
$\mathrm{MeOH} / \mathrm{PhMe} \rightarrow 10 \% \mathrm{MeOH} / \mathrm{PhMe}$ ) yielded COP-6VP as a light yellow solid $(65 \mathrm{mg}, 63 \%): \delta 8.57-8.55(\mathrm{~m}, 18 \mathrm{H})$ 7.60-7.22 (m, 39H), 7.05-6.99 (m, $18 \mathrm{H}), 6.70-6.64(\mathrm{~m}, 12 \mathrm{H}), 4.39(\mathrm{~s}, 12 \mathrm{H}), 4.09(\mathrm{br} \mathrm{s}, 6 \mathrm{H}), 3.98(\mathrm{t}, J=6.5 \mathrm{~Hz}$, $6 \mathrm{H}), 2.05-2.01(\mathrm{~m}, 12 \mathrm{H}), 1.82-1.71(\mathrm{~m}, 6 \mathrm{H}), 1.64-1.56(\mathrm{~m}, 6 \mathrm{H}), 1.40-$ $1.18(\mathrm{~m}, 72 \mathrm{H}), 1.00-0.96(\mathrm{~m}, 12 \mathrm{H}), 0.88-0.81(\mathrm{~m}, 36 \mathrm{H}), 0.78-0.66(\mathrm{~m}, 27 \mathrm{H})$; MS (MALDI) calc'd for $\mathrm{C}_{246} \mathrm{H}_{283} \mathrm{~N}_{12} \mathrm{O}_{3}\left([\mathrm{M}+\mathrm{H}]^{+}\right)$3455.24, found 3455.78.
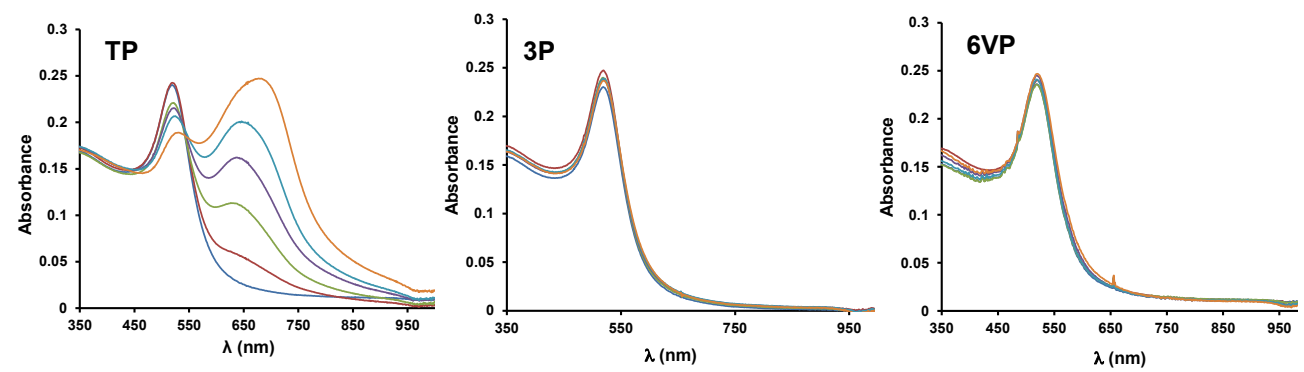

Figure S1. Titration study: TP $(50 \mu \mathrm{M})$, COP-3P $(50 \mu \mathrm{M})$, and COP-6VP $(50 \mu \mathrm{M})$ in THF were added $(0-25 \mu \mathrm{L}$ in $5 \mu \mathrm{L}$ increments) to aqueous solutions of AuNPs $(0.5 \mathrm{~mL})$. After mixing the components, they were diluted to $5 \mathrm{~mL}$ and the absorption spectra were recorded. 